\title{
Assessment of tributyltin contamination based on imposex in Stramonita rustica (Mollusca: Gastropoda) along southern Bahia coast, northeastern Brazil
}

\author{
G. C. Zeidan ${ }^{a}$ and G. Boehs ${ }^{a}$ \\ aLaboratory of Marine Mollusks, Postgraduate Animal Science Program, Universidade Estadual de Santa Cruz - UESC, \\ Rodovia Jorge Amado, Km 16, CEP 45662-900, Ilhéus, BA, Brazil \\ *e-mail: gabizeidan@hotmail.com
}

Received: September 22, 2015 - Accepted: December 4, 2015 - Distributed: February 28, 2017

(With 2 figures)

\begin{abstract}
This study investigated the effects of tributyltin (TBT) on the morphology of the genital system of the gastropod Stramonita rustica in southern Bahia, Brazil. For this, 330 specimens were collected during the summer of 2014 at eight sampling points to ascertain whether male sex organs had developed in addition to the complete female genital tract in females (= imposex). The analyses were made under a stereoscopic microscope. Imposex and their associated indexes, and the sterile females, exhibited the highest rates in harbors and shipyards areas. Despite the total ban of TBT in anti-fouling paints on a global scale since 2003, the results of this and other studies indicate the continued use of those paints on the Brazilian coast. This shows the inefficiency of existing legislation and the need to strengthen enforcement of the ban.
\end{abstract}

Keywords: antifouling, sterilization, harbors, TBT.

\section{Avaliação da contaminação por tributil-estanho baseada em imposex em Stramonita rustica (Mollusca: Gastropoda) ao longo do Litoral Sul da Bahia}

\section{Resumo}

Este estudo investigou os efeitos de tributil-estanho (TBT) sobre a morfologia do sistema genital do gastrópode Stramonita rustica (Lamarck, 1822) no Litoral Sul da Bahia, Brasil. Para isso, 330 espécimens foram coletados durante o verão de 2014 em oito pontos de amostragem, para verificar se os órgãos sexuais masculinos tinham se desenvolvido para além do trato genital feminino completo (= imposex). As análises foram feitas sob um microscópio estereoscópico. O imposex e seus índices associados, assim como as fêmeas estéreis, apresentaram as maiores taxas em áreas portuárias e estaleiros. Apesar da proibição total do TBT em tintas anti-incrustantes em escala global desde 2003, os resultados deste e de outros estudos indicam a continuidade de uso dessas tintas na costa brasileira. Isso mostra a ineficácia da legislação vigente e reforça a necessidade de se cumprir integralmente o banimento.

Palavras-chave: antifouling, esterilização, portos, TBT.

\section{Introduction}

The organic compound Tributyltin (TBT), used as biocides in antifouling paints since the mid 1960s was considered by Goldberg (1986) to present the highest toxicity among compounds and to be the most harmful anthropogenic contaminant ever produced and deliberately introduced into aquatic ecosystems. Because of the adverse effects of TBT on marine organisms, the International Marine Organization (IMO) imposed a worldwide ban on its use in marine applications in 2003, to effectively force in 2008 (Bekri et al., 2006). In Brazil, the Brazilian Navy (BN) suspended the use of TBT - bases antifouling paints on its vessels in 2003 too. But, small boats continued using antifouling paints with TBT. Because of this, in 2007 the
NORMAM 23 (BN) restricted the use of organotin compounds in antifouling products on all Brazilian registered vessels. Despite the prohibitions in national and global level, the TBTs are still being used in many countries, including Brazil (Santos et al., 2011).

TBT can cause negative effects in various taxonomic groups and, among these, mollusks appear to be the invertebrates that are the most sensitive to this compound (Bryan and Gibbs, 1991). Consequently, these organisms are excellent sentinels for monitoring TBT in marine environments (Shim et al., 2002). For example, TBT is the leading cause of defects in bivalve shells (Bryan and 
Gibbs, 1991) and also acts as an endocrine disrupter in gastropods (Smith, 1971).

Imposex occurs in neogastropods, and is characterized by development of male sex organs (penis and/or vas deferens) in addition to a complete female genital tract (Smith, 1971). Because this syndrome is easy to diagnose, it has been successfully used as a biological effect monitoring system to determine the presence and degree of environmental TBT pollution. Currently, imposex is widely distributed (DeFur et al., 1999), and approximately 260 known species of neogastropods are affected (Titley-O'Neal et al., 2011).

The southern coast of Bahia, in northeastern Brazil, has high levels of boating activity, with the presence of harbors, shipyards, marinas and numerous moorings for small boats. Moreover, it is a geographically diverse region, with the presence of mangroves, coral reefs and sandstone banks along its coast. To date, there is no information about the action of TBT on marine organisms in this area.

The aim of this study was to investigate TBT contamination in this region, using imposex as biomarker in Stramonita rustica (Neogastropoda: Muricidae).

\section{Material and Methods}

\subsection{Samples}

The samples were taken during the summer of 2014 between latitudes 13 to $16^{\circ} \mathrm{S}$, in southern Bahia (Figure 1). Stramonita rustica $(\mathrm{n}=330)$ was collected from environments with hard substrata such as rocks, sandstone banks and coral reefs, all close to harbors, boating activity and marinas with frequent small-boat activity. The sampling points were chosen according to occurrences of the species in representative quantities per catch $(n \geq 30)$, and also according to the presence of fishing and port activities. Thus, the municipalities of Ilhéus, Maraú, Itacaré and Canavieiras were investigated, but this species was not found at the last two of these places.

This collections were made with permission for activities with scientific purpose issued by Authorization and Information System of Biodiversity- SISBIO/ Chico Mendes Institute for Biodiversity Conservation - ICMBio of Brazil (concessions number: 20912-3.

\subsection{Laboratory processing}

All the snails were measured to the nearest $0.01 \mathrm{~mm}$ with calipers and then they were narcotized in a $7 \%$ (w/v) magnesium chloride $\left(\mathrm{MgCl}_{2}\right)$ solution for one hour. Following this, we cracked the shell in a vise. The external morphology of the genital system was analyzed under a stereomicroscope. The penis length was measured to the nearest $0.1 \mathrm{~mm}$ with a caliper. The sex ratio (M: F) was calculated as described by Birchenough et al. (2002). We also calculated the percentage of females with sexual morphological changes as I (\%). To determine the levels of imposex, we evaluated the mean female (FPL) and male (MPL) penis lengths, by using the relative penis length (RPL) calculation proposed by Gibbs and Bryan (1987).
We also calculated the vas deferens sequence index (VDS) proposed by Gibbs and Bryan (1994).

\subsection{Statistical analyzes}

A matrix using Pearson coefficients was created to examine correlations between snail size and penis length in both female and male specimens at each site; the Kruskal-Wallis test was also used to verify differences in snail size and penis length, in both sexes. All analyses were performed using the Statistica software package. The significance level used was $95 \%$.

\section{Results and Discussion}

Imposex was observed at seven of the eight monitoring stations (St) (Figure 2). This syndrome did not occur at St3, where boating activity is virtually absent and where there is high hydrodynamic activity, thereby resulting in stronger circulation and more frequent water renewal than at the other sampling points (Figure 2). Among the total number of females collected $(\mathrm{n}=178), 30$ specimens (16.39\%) exhibited imposex. However, despite low index values, sterile females were observed at both St2 and St5 (vas deferens sequence index $=$ VDS $=4)$ (Table 1; Figure 2). These stations showed also the highest $\mathrm{I} \%$ (females with sexual morphological changes). According to Barroso et al. (2002), FPL (mean female penis length), VDS, I\% and percentage of sterile females are generally the main indices that have been applied for evaluating imposex intensity in prosobranchs.

According to Bryan et al. (1986), the relative penis length index (RPL) can be used to describe the severity of imposex. We found large differences among the mean values of the RPL (relative penis length) at different sampling stations (Table 1). The stations closest to harbors and to fishing and boat maintenance activities had the lowest average RPL values, while the station farthest from nautical activities showed the highest RPL value (Figure 2). This result should be correlated with different timescale variations of exposure to TBT, and also to its spatial distribution (Smith, 1996; Barroso and Moreira, 1998; Rato et al., 2008). The RPL found in the St7 was one of the largest of northeast. This station is to close to the international exportation harbour of the city and had been lower only of the RPL found by Castro et al. (2008) in Alagoas and Sergipe. Despite of indexes taking penis length as their basis are viewed with reservations, given the possible relationship with testicular maturation and time of year (Rato et al., 2008), we consider that the RPL results of our study are reliable, since all specimens were collected at the same time.

With regard to the total sex ratio, the values were generally higher for females (Table 1). However, the sample stations that showed higher male values were the same ones that had higher frequency of imposex (Figure 2) and corresponded to areas with great nautical activity, which thus confirmed the results obtained from other studies (Miller et al., 1999; Shim et al., 2002). 


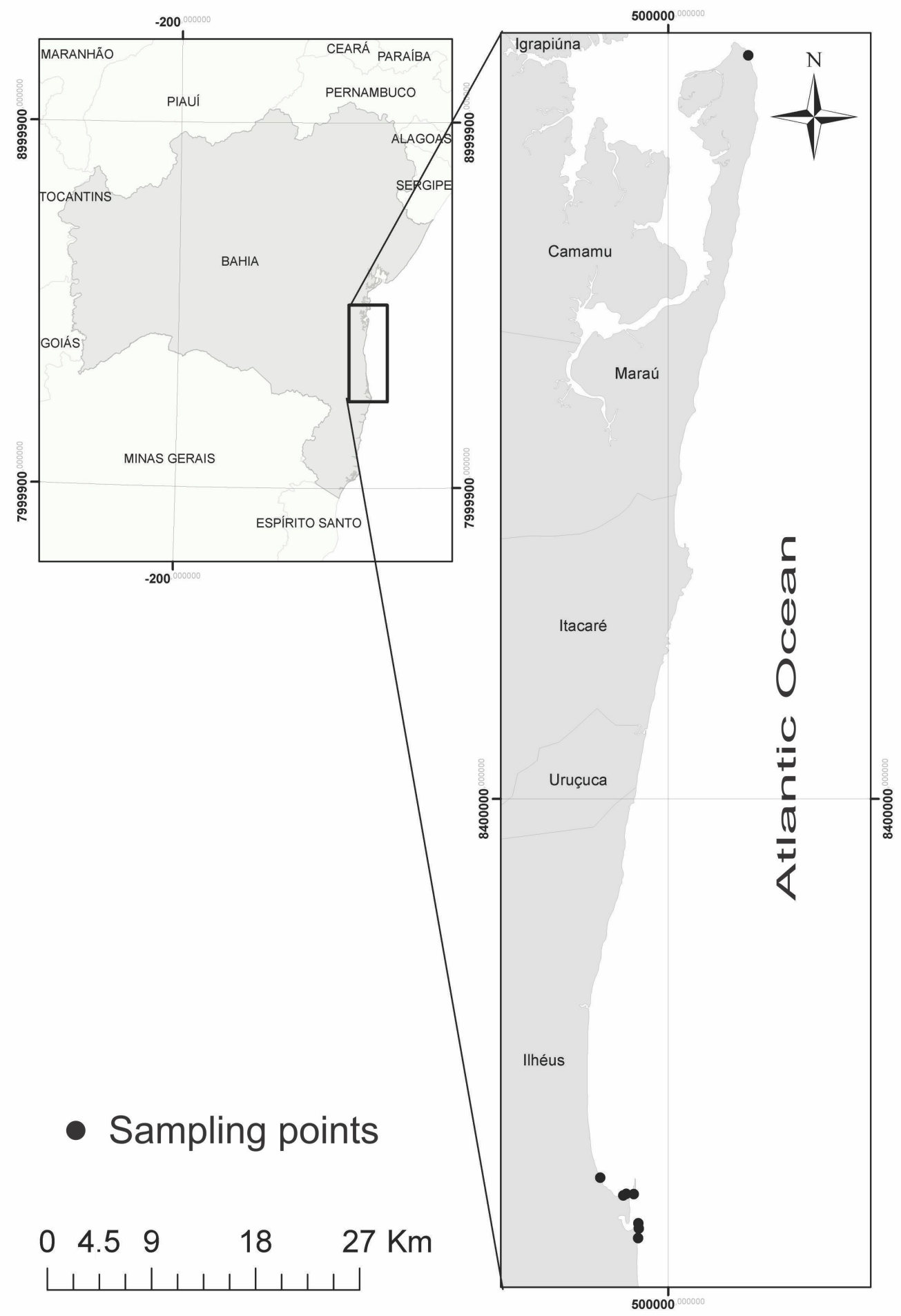

Figure 1. Map showing the sampling points along the southern coast of Bahia.

Although some authors have considered that imposex causes changes to the growth rate of females due to higher allocation of energy (Terlizzi et al., 1999; Trigui El-Menif et al., 2006), we observed that females were generally larger than males (average $=24.07 \mathrm{~mm}$,
$\mathrm{SD} \pm 5.51$; and $23.97 \mathrm{~mm}, \mathrm{SD} \pm 5.52$, respectively), but this difference was not significant in relation to length and station $(p>0.05)$. These findings indicated the presence not only of natural specific variation but also of low environmental contamination by TBT, as was proposed 

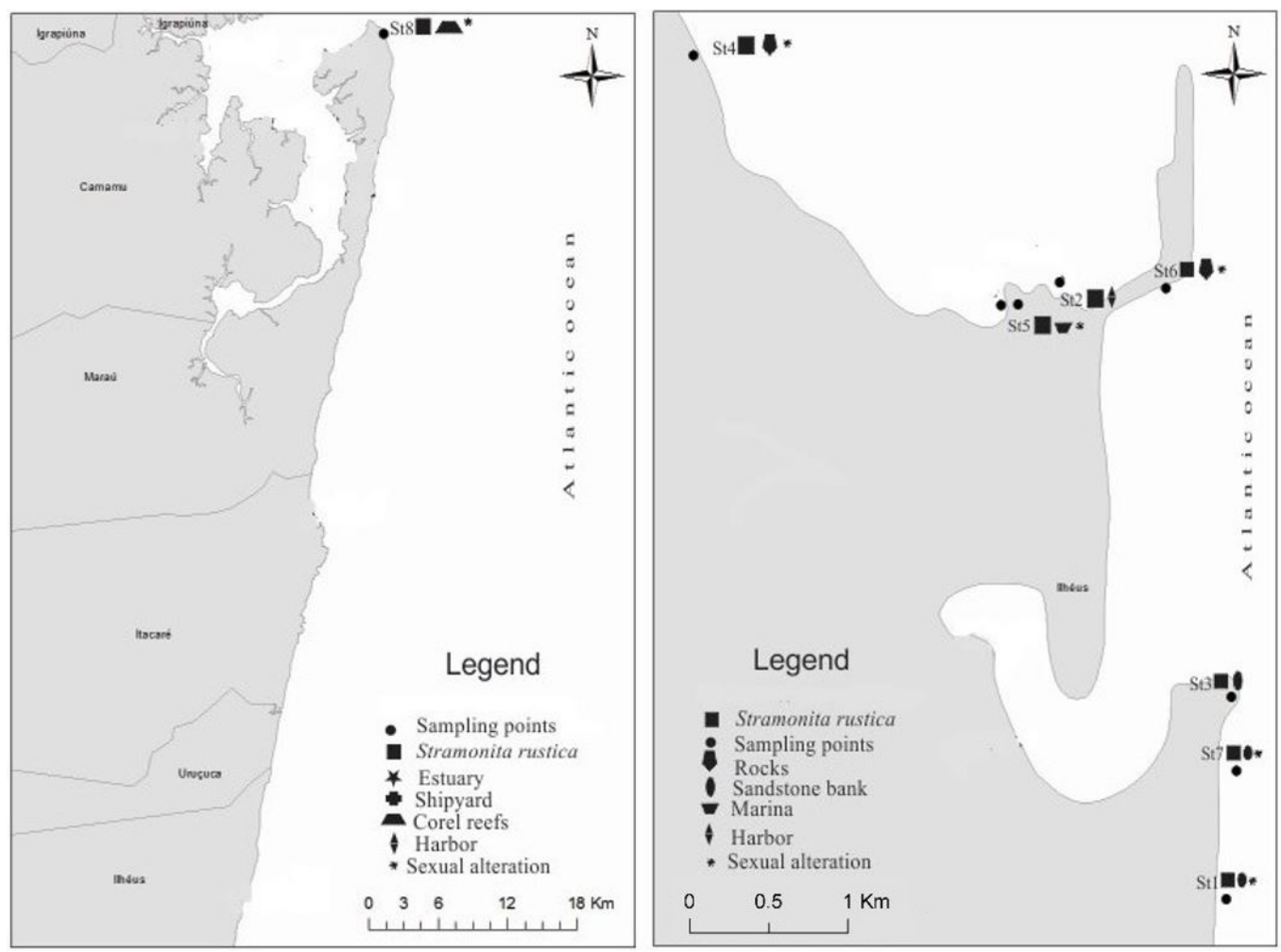

Figure 2. Monitored stations on southern Bahia coast indicating sampling stations, locations of main boating activity and sexual alterations, being: Ilhéus region and Maraú region.

Table 1. Imposex data for Stramonita rustica on the southern coast of Bahia, Brazil.

\begin{tabular}{|c|c|c|c|c|c|c|c|c|c|}
\hline $\begin{array}{l}\text { Sample } \\
\text { Stations }\end{array}$ & $\begin{array}{l}\text { Geografic } \\
\text { Coordinates }\end{array}$ & F M & $\begin{array}{l}\text { Sex } \\
\text { ratio }\end{array}$ & $\begin{array}{c}\text { Shell height } \\
(\text { Mean } \pm \text { SD) } \\
(\mathbf{m m}) \\
\text { F } \\
\end{array}$ & $\begin{array}{c}\text { Shell height } \\
\text { (Mean } \pm \text { SD) } \\
(\mathrm{mm}) \\
\text { M }\end{array}$ & $\begin{array}{c}\text { FPL } \\
(\text { Mean } \pm \text { SD }) \\
(\mathbf{m m})\end{array}$ & $\begin{array}{l}\text { RPL } \\
(\%)\end{array}$ & $\begin{array}{l}\text { Imposex } \\
\text { frequency } \\
\quad(\%)\end{array}$ & VDS \\
\hline St1 & $\begin{array}{c}14^{\circ} 49^{\prime} 2.28^{\prime \prime} \mathrm{S} \\
39^{\circ} 1 \text { 1'26.86” W }\end{array}$ & $\begin{array}{l}20 \\
10 \\
\end{array}$ & 0.85 & $26.03 \pm 2.17$ & $25.87 \pm 1.53$ & $0.54 \pm 0.26$ & 21.35 & 0.17 & 0.4 \\
\hline St2 & $\begin{array}{c}14^{\circ} 46^{\prime} 58.59^{\prime \prime} \mathrm{S} \\
39^{\circ} 2^{\prime} 1.10^{\prime \prime} \mathrm{W}\end{array}$ & $\begin{array}{l}30 \\
30\end{array}$ & 1 & $24.04 \pm 1.97$ & $26.76 \pm 3.71$ & $0.05 \pm 0.00$ & 0.96 & 16.66 & $0.48 *$ \\
\hline St3 & $\begin{array}{l}14^{\circ} 48^{\prime} 21.74^{\prime \prime} \mathrm{S} \\
39^{\circ} 1 \text { 1'25.79" W }\end{array}$ & $\begin{array}{l}20 \\
10 \\
\end{array}$ & 0.5 & $27.65 \pm 3.74$ & $24.34 \pm 2.01$ & - & - & - & - \\
\hline St4 & $\begin{array}{l}14^{\circ} 46^{\prime} 13.13^{\prime \prime} \mathrm{S} \\
39^{\circ} 3,16.60^{\prime \prime} \mathrm{W}\end{array}$ & $\begin{array}{l}28 \\
32\end{array}$ & 1.14 & $21.68 \pm 3.65$ & $21.54 \pm 3.66$ & $0.54 \pm 0.04$ & 17.12 & 11.53 & 0.10 \\
\hline St5 & $\begin{array}{l}14^{\circ} 47^{\prime} 2.93 ” \mathrm{~S} \\
39^{\circ} 2{ }^{\prime} 9.63 ” \mathrm{~W}\end{array}$ & $\begin{array}{l}30 \\
30\end{array}$ & 1 & $19.00 \pm 8.32$ & $20.89 \pm 8.48$ & $0.54 \pm 0.00$ & 1.88 & 20 & 0.43 \\
\hline St6 & $\begin{array}{l}14^{\circ} 46^{\prime} 59.69^{\prime \prime} \mathrm{S} \\
39^{\circ} 1{ }^{\prime} 39.24 ” \mathrm{~W}\end{array}$ & $\begin{array}{l}18 \\
12 \\
\end{array}$ & 0.8 & $27.34 \pm 1.63$ & $26.97 \pm 1.82$ & $0.05 \pm 0.00$ & 3.21 & 0.2 & 0.61 \\
\hline St7 & $\begin{array}{l}14^{\circ} 48^{\prime} 36.47^{\prime \prime} \mathrm{S} \\
39^{\circ} 1 \text { 1'24.62” W }\end{array}$ & $\begin{array}{l}16 \\
14 \\
\end{array}$ & 0.87 & $26.10 \pm 1.59$ & $25.85 \pm 1.61$ & $0.78 \pm 0.81$ & 26.0 & 0.6 & 0.93 \\
\hline St8 & $\begin{array}{l}13^{\circ} 53^{\prime} 21.64^{\prime \prime} \mathrm{S} \\
38^{\circ} 56^{\prime} 7.67^{\prime \prime} \mathrm{W}\end{array}$ & $\begin{array}{l}16 \\
14\end{array}$ & 0.87 & $23.40 \pm 4.45$ & $22.66 \pm 5.37$ & $0.41 \pm 0.54$ & 6.76 & 0.5 & 0.8 \\
\hline
\end{tabular}

$\mathrm{F}=$ female $\mathrm{M}=$ male $; \mathrm{SD}=$ square degree; $\mathrm{FPL}=$ average female penis length; $\mathrm{RPL}=$ relative penis length index $(=\mathrm{FPL} /$ average male penis length $x$ 100); VDS = vas deferens sequence index; - = no occurrence.* Occurrence of sterile females; $n=330$.

by Vasconcelos et al. (2010). Regarding penis length, we found a significant morphometric difference between males and imposexed females, but there was no difference in male penis length between the sample stations (Table 2).
This showed that, at least in our study, TBT did not seem to cause changes in males.

Imposex induced by TBT are irreversible, i.e., cannot be reversed to the normal morphological situation or reduced 
Table 2. Results from Kruskal-Wallis analysis on the penis length of Stramonita rustica between males and females and between sample stations.

\begin{tabular}{ccccc}
\hline Variable & $\begin{array}{c}\text { Source } \\
\text { of } \\
\text { variation }\end{array}$ & $\begin{array}{c}\text { Degree } \\
\text { of } \\
\text { freedom }\end{array}$ & W & P \\
\hline $\begin{array}{c}\text { Penis } \\
\text { length }\end{array}$ & Sex & 1 & 74,30966113 & $\mathrm{p}<0.001$ \\
& & & & \\
& Stations & 7 & 93,21896858 & $\mathrm{p}>0.05$ \\
\hline $\mathrm{W}=$ test values; $\mathrm{p}=$ probability of $\alpha$ error $(\alpha=0.05)$.
\end{tabular}

to a lower stage, even if the gastropods are subsequently kept under TBT-free conditions (Oehlmann et al., 1998). Regarding S. rustica, the data from the present study showed that there was widespread use of TBT in southern Bahia. In studies conducted by Castro et al. (2007, 2008) along the northeastern coast of Brazil using S. rustica and $S$. haemastoma as bioindicators, it could be seen that the first species was less sensitive than S. haemastoma, i.e., S. rustica showed lower RPL and VDS values at the same collection points. These data, together with possibly relatively low TBT contamination in our study area, may explain the low imposex rates in southern Bahia.

In analyzing our results, we can say that the frequencies of imposex tended to be higher in areas with harbors, small-boat maintenance activities and docks. Similar results have been observed worldwide: on the northeastern Brazilian coast, in relation to $S$. rustica (Castro et al., 2007, 2008), in the Mediterranean, in relation to Hexaplex trunculus (L.) (Axiak et al., 1995), and in several harbors in Europe and in Halifax harbor, Canada, in relation to Nucella lapillus (L.) (Sousa et al., 2009). Other studies have also confirmed that areas near harbors and marinas are hotspots for TBT pollution (Barroso et al., 2002; Sousa et al., 2005).

In conclusion, although the TBT contamination levels seem to be bland in southern Bahia, the reproduction of $S$. rustica was compromised. This suggest the need for compliance and supervision of international and national legislation.

\section{Acknowledgements}

We are grateful to Leonice Freitas, Glaucia Maciel and William Fróes for their assistance during the sampling campaigns. We are also grateful to Dr. Mércia Costa (Federal University of Espírito Santo, Brazil) for sharing her techniques and knowledge. This study was supported by FAPESB (Bahia, Brazil), under grant number TSC $0010 / 2011$, and through a doctoral scholarship granted to the first author.

\section{References}

AXIAK, V., VELLA, A.J., MICALLEF, D., CHIRCOP, P. and MINTOFF, B., 1995. Imposex in Hexaplex trunculus (Gastropoda: Muricidae): first results from biomonitoring of tributyltin contamination in the Mediterranean. Marine Biology, vol. 121, no. 4, pp. 685-691. http://dx.doi.org/10.1007/BF00349304.
BARROSO, C.M. and MOREIRA, M.H., 1998. Reproductive cycle of Nassarius reticulatus in the Ria de Aveiro, Portugal: implications for imposex studies. Journal of the Marine Biological Association of the United Kingdom, vol. 78, no. 4, pp. 1233-1246. http://dx.doi.org/10.1017/S0025315400044453.

BARROSO, C.M., MOREIRA, M.H. and BEBIANNO, M.J., 2002. Imposex, female sterility and organotin contamination of the prosobranch Nassarius reticulatus (L.) from the Portuguese coast. Marine Ecology Progress Series, vol. 230, pp. 127-135. http://dx.doi.org/10.3354/meps230127.

BEKRI, K., SAINT-LOUIS, R. and PELLETIER, E., 2006. Determination of tributyltin and 4-hydroxybutyldibutyltin chlorides in seawater by liquid chromatography with atmospheric pressure chemical ionization-mass spectrometry. Analytica Chimica Acta, vol. 578, no. 2, pp. 203-212. http://dx.doi.org/10.1016/j. aca.2006.06.069. PMid:17723713.

BIRCHENOUGH, A.C., BARNES, N., EVANS, S.M., HINZ, H., KRÖNKE, I. and MOSS, C., 2002. A review and assessment of tributyltin contamination in the North Sea, based on surveys of butyltin tissue burdens and imposex/intersex in four species of neogastropods. Marine Pollution Bulletin, vol. 44, no. 6, pp. 534-543. http://dx.doi.org/10.1016/S0025-326X(01)00275-2. PMid:12146836.

BRYAN, G.W. and GIBBS, P.E., 1991. Impact of low concentration of tributyltin (TBT) on marine organisms: a review. In: M.C. NEWMAN and A.W. MCINTOSH. Metal ecotoxicology: concepts and applications. Ann Arbor: Lewis Publishers, pp. 323-361

BRYAN, G.W., GIBBS, P.E., HUMMERSTONE, L.G. and BURT, G.R., 1986. The decline of the gastropod Nucella lapillus around south west England: evidence for the effect of tributyltin from antifouling paints. Journal of the Marine Biological Association of the United Kingdom, vol. 66, no. 3, pp. 611-640. http://dx.doi. org/10.1017/S0025315400042247.

CASTRO, I.B., ALVES DE LIMA, A.F., BRAGA, A.R.C. and ROCHA-BARREIRA, C.A., 2007. Imposex in two muricid species (Mollusca: Gastropoda) from the northeastern Brazilian coast. Journal of Brazilian Society of Ecotoxicology, vol. 2, no. 1, pp. 81-91. http://dx.doi.org/10.5132/jbse.2007.01.012.

CASTRO, I.B., DE MEIRELLES, C.A.O., MATTHEWSCASCON, H., ROCHA-BARREIRA, C.D., PENCHASZADEH, P. and BIGATTI, G., 2008. Imposex in endemic Volutid from northeast Brazil (Mollusca: Gastropoda). Brazillian Archives of Biology Technices, vol. 51, pp. 1065-1069.

DEFUR, P.L., CRANE, M., INGERSOLL, C.G. and TATTERSFIELD, L., 1999. Endocrine disruption in invertebrates: endocrinology, testing and assessment. Pensacola: Society for Environmental Toxicology and Chemistry.

GIBBS, P.E. and BRYAN, G.W., 1987. TBT paints and demise of the dog-whelk Nucella lapillus (Gastropoda). Journal of the Marine Biological Association of the United Kingdom, vol. 68, pp. 1482-1487.

GIBBS, P.E. and BRYAN, G.W., 1994. Biomonitoring of tributyltin (TBT) pollution using the imposex response of neogastropod molluscs. In: J. KESS and M. KRAME. Biomonitoring of coastal waters and estuaries. Boca Raton: CRC Press, pp. 205-226.

GOLDBERG, E.D., 1986. TBT: an environmental dilemma. Environment, Science and Policy for Sustainable Development, vol. 28, no. 8, pp. 17-44. http://dx.doi.org/10.1080/00139157.1 986.9928814 . 
MILLER, K.L., FERNANDES, T.F. and READ, P.A., 1999. The recovery of populations of dogwhelks suffering from imposex in the Firth of Forth 1987-1997/98. Environmental Pollution, vol. 106, no. 2, pp. 183-192. http://dx.doi.org/10.1016/S02697491(99)00076-7. PMid:15093045.

OEHLMANN, J., BAUER, B., MINCHIN, D., SCHULTEOEHLMANN, U., FIORONI, P. and MARKERT, B., 1998. Imposex in Nucella lapillus and intersex in Littorina littorea: interspecific comparison of two TBT-induced effects and their geographical uniformity. Hydrobiologia, vol. 378, no. 1/3, pp. 199-213. http://dx.doi.org/10.1023/A:1003218411850.

RATO, M., GASPAR, M.B., TAKAHASHI, S., YANO, S., TANABE, S. and BARROSO, C.M., 2008. Inshore/offshore gradients of imposex and organotin contamination in Nassarius reticulatus (L.) along the Portuguese coast. Marine Pollution Bulletin, vol. 56, no. 7, pp. 1323-1331. http://dx.doi.org/10.1016/j. marpolbul.2008.04.004. PMid:18501385.

SANTOS, D.M., SANT’ANNA, B.S., GODOI, A.F.L., TURRA, A. and MARCHI, M.R.R., 2011. Contamination and impact of organotin compounds on the Brazilian Coast. In: A.C. ORTIZ and N.B. GRIFfiN. Pollution monitoring. Hauppauge: N. Science Publishers, pp. 31-59.

SHIM, W.J., HONG, S.H., YIM, U.H., KIM, N.S. and OH, J.R., 2002. Horizontal and vertical distribution of butyltin compounds in sediments from shipyards in Korea. Archives of Environmental Contamination and Toxicology, vol. 43, no. 3, pp. 277-283. http:// dx.doi.org/10.1007/s00244-002-0156-0. PMid:12202922.

SMITH, B.S., 1971. Sexuality in the American mud snail, Nassaruis obsoletus. Proceedings of the Malacological Society of London, vol. 39, pp. 377-378.

SMITH, P.J., 1996. Selective decline in imposex levels in the dogwhelk Lepsiella scobina following a ban on the use of TBT antifoulants in New Zealand. Marine Pollution Bulletin, vol. 32, no. 4, pp. 362-365. http://dx.doi.org/10.1016/0025-326X(96)84830-2.

SOUSA, A., LARANJEIRO, F., TAKAHASHI, S., TANABE, S. and BARROSO, C.M., 2009. Imposex and organotin prevalence in a European post-legislative scenario: temporal trends from 2003 to 2008. Chemosphere, vol. 77, no. 4, pp. 566-573. http:// dx.doi.org/10.1016/j.chemosphere.2009.06.049. PMid:19656548.

SOUSA, A., MENDO, S. and BARROSO, C.M., 2005. Imposex and organotin contamination in Nassarius reticulatus (L.) along the Portuguese coast. Applied Organometallic Chemistry, vol. 19, no. 3, pp. 315-323. http://dx.doi.org/10.1002/aoc.856.

TERLIZZI, A., GERACI, S. and GIBBS, P.E., 1999. Tributyltin (TBT)-induced imposex in the Neogastropod Hexaplex trunculus in Italian coastal waters: morphological aspects and ecological implications. The Italian Journal of Zoology, vol. 66, no. 2, pp. 141-146. http://dx.doi.org/10.1080/11250009909356248.

TITLEY-O'NEAL, C.P., MUNKITTRICK, K.R. and MACDONALD, B.A., 2011. The effects of organotinon female gastropods. Journal of Environmental Monitoring, vol. 13, no. 9, pp. 2360-2388. http:// dx.doi.org/10.1039/c1em10011d.

TRIGUI EL-MENIF, N., LAHBIB, Y., LE PENNEC, M., FLOWER, R. and BOUMAIZA, M., 2006. Intensity of the imposex phenomenon impact on growth and fecundity in Hexaplex trunculus (Mollusca: Gastropoda) collected in Bizerta lagoon and channel (Tunisia). Cahiers de Biologie Marine, vol. 47, pp. 1-11.

VASCONCELOS, P., MOURA, P., BARROSO, C.M. and GASPAR, M.B., 2010. Size matters: importance of penis length variation on reproduction studies and imposex monitoring in Bolinus brandaris (Gastropoda: Muricidae). Hydrobiologia, vol. 661, no. 1, pp. 363-375. http://dx.doi.org/10.1007/s10750-010-0544-9. 